\title{
Human-wildlife conflict in northern Botswana: livestock predation by Endangered African wild dog Lycaon pictus and other carnivores
}

\author{
M. Gusset, M.J.Swarner, L. Mponwane, K. Keletile and J.W. McNutt
}

\begin{abstract}
We conducted a questionnaire survey among 77 cattle posts and farms to investigate human-carnivore conflicts in northern Botswana, with a particular focus on Endangered African wild dog Lycaon pictus, persecuted throughout their shrinking range in sub-Saharan Africa for allegedly predating livestock. Predator attacks on livestock ( $\mathrm{n}=938$ conflict reports) represent an economic concern for livestock owners, particularly alleged predation by black-backed jackal Canis mesomelas, which were blamed for $77 \%$ of all reported livestock losses. The presence of two known resident packs of wild dogs did not result in corresponding conflict reports with livestock owners, as wild dogs accounted for only $2 \%$ of reported predator attacks and largely subsisted on wild prey. Nevertheless, most of these wild dogs were killed in the months following this survey. Reported conflicts involving the two largest predator species (lion Panthera leo and spotted hyaena Crocuta crocuta) declined with increasing distance from protected areas. Leaving livestock unattended during the day seems to facilitate predation but kraaling livestock at night reduces predation. Compensation payments for livestock losses did not demonstrably change livestock owners' willingness to coexist with predators. Our results corroborate studies from elsewhere that simple improvements in livestock husbandry practices would help mitigate human-carnivore conflicts.
\end{abstract}

Keywords Compensation, human-wildlife conflict, livestock husbandry, livestock predation, Lycaon pictus.

\section{Introduction}

T uman-wildlife conflict often undermines the objectives 1 of wildlife conservation and sustainable use initiatives. Although the benefits of utilizing wildlife may be directed to communities through community-based natural resource management (CBNRM) programmes (Du Toit, 2002), wildlife threats to human life and property impair these benefits and engender negative attitudes towards wildlife while

M. Gusset* (Corresponding author), M.J. Swarner, L. Mponwane, K. Keletile and J.W. McNutt Botswana Predator Conservation Program, Private Bag 13, Maun, Botswana. E-mail mgusset@bluewin.ch

${ }^{*}$ Current address: Leipzig Zoo, Pfaffendorfer Strasse 29, 04105 Leipzig, Germany.

Received 17 March 2008. Revision requested 16 May 2008.

Accepted 4 July 2008. eroding the absolute value of the natural resource. Diversification of the economy may be critical for the long-term economic viability of developing countries, such as the continued development of sustainable CBNRM programmes (Berkes, 2004). However, inability to address human-wildlife conflicts at the community level threatens this potentially important area of economic growth (Madden, 2004), a problem that is often exacerbated by a lack of basic understanding of the dimension of the problem.

Free-ranging large carnivores constitute one of the most prominent human-wildlife conflict issues. Ultimately, the degree to which communities support and participate in predator conservation will depend on the value that people place on predators (Sillero-Zubiri \& Laurenson, 2001). This value is likely to be a function of costs (e.g. livestock losses or threats to peoples' lives) and benefits (e.g. tourist revenues or cultural values) resulting from the presence of predators. Livestock predation in particular has been a serious challenge to conserving threatened predators outside protected areas (Treves \& Karanth, 2003), with predators potentially adversely affecting the profitability of livestock production and people's livelihoods. Accordingly, the outside boundaries of protected areas often represent an anthropogenic sink for predator populations (Woodroffe \& Ginsberg, 1998).

This human-wildlife conflict is exemplified by the situation in northern Botswana, where the expansion of livestock into relatively natural wildlife areas, particularly in the buffer zones (Wildlife Management Areas) adjacent to Moremi Game Reserve and Chobe National Park, has resulted in an increase in livestock predation reports (Tjibae, 2001). It has been speculated that these livestock losses are in part a consequence of abandoning traditional livestock husbandry practices in Botswana (Tjibae, 2001). Details are lacking on the actual extent of livestock losses caused by predators but the conflict has led to considerable numbers of predators being killed as so-called problem animals and an estimated BWP 1,000,000 (USD 162,000) is spent annually on livestock compensation payments (Tjibae, 2001). With the number of CBNRM programmes growing in Botswana's wildlife areas (Arntzen et al., 2003), mitigating human-carnivore conflicts is likely to become increasingly important.

Endangered African wild dog Lycaon pictus are persecuted throughout their shrinking range in sub-Saharan Africa for allegedly predating livestock (Rasmussen, 1999; Woodroffe et al., 2005; IUCN, 2007). However, whether wild 
dogs have actually been responsible for claimed livestock losses is often questionable. Therefore, to add to the understanding of human-wild dog conflict in northern Botswana we conducted a questionnaire survey among cattle posts and farms in areas where radio-collared wild dogs were resident. Results of this survey enabled us to relate livestock losses specifically to the known distribution of wild dogs in the study area and to place human-wild dog conflict in a wider context through comparison with other human-carnivore conflicts. The findings of this study should thus be helpful in implementing measures to ameliorate the relationship between people and carnivores.

\section{Study area}

Northern Botswana comprises the arid northern extension of the Kalahari Desert and the Okavango Delta, an alluvial freshwater ecosystem that is one of southern Africa's richest wildlife regions and supports a thriving wildlife tourism industry. An extensive veterinary cordon fence divides protected areas from adjacent livestock grazing areas. The survey reported here was conducted in cattle posts adjacent to the veterinary cordon fence in the southern part of the wild dog study area (see McNutt, 1996, for a detailed description), from Daonara gate to Makalamabedi gate (Shorobe survey block), cattle posts to the south, from Makalamabedi village to Samedupi village (Samedupi survey block), and cattle posts and farms in the northern Hainaveldt (Hainaveldt survey block) further away from the veterinary cordon fence (Fig. 1). Large carnivores, which commonly pass through the veterinary cordon fence, include lion Panthera leo, leopard Panthera pardus, cheetah Acinonyx jubatus, caracal Caracal caracal, spotted hyaena Crocuta crocuta, wild dog, and black-backed jackal Canis mesomelas. Except for two resident packs of wild dogs, the distribution and abundance of these predators in the livestock grazing areas is largely unknown.

\section{Methods}

Field research on wild dogs in and adjacent to Moremi Game Reserve has been ongoing since 1989. One goal of this

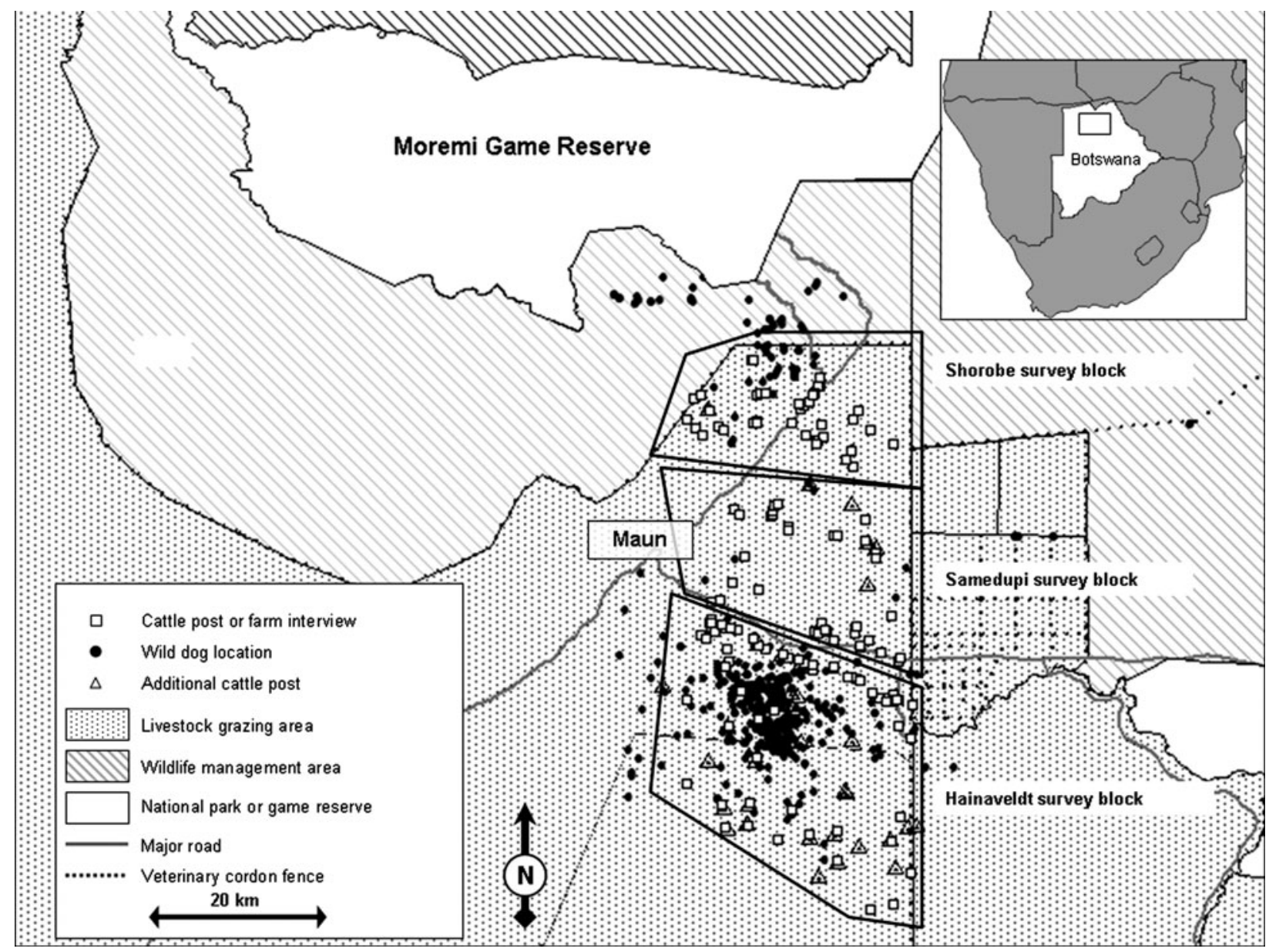

FIG. 1 Northern Botswana showing general land use, the three survey blocks with cattle posts and farms (including additional cattle posts not visited) and the known distribution of two radio-collared wild dog packs resident in the survey areas. Rectangle on inset indicates the position of the main map in northern Botswana. 
long-term study has been to determine the factors that limit this wild dog population, including human impact. In the present study, two wild dogs per pack were collared with VHF transmitters in the months prior to their dispersal (cf. Osofsky et al., 1996) and a satellite/VHF radio collar was later added to the furthest dispersed pack (in the Hainaveldt survey block). The wild dogs' distribution in the study area was monitored, mapped with a global positioning system (GPS) and coordinates transferred to the geographical information system (GIS) ArcView v. 3.2 (ESRI, Redlands, USA) before, during and after the questionnaire survey (Fig. 1).

A total of 64 cattle posts and 13 farms were visited in September-October 2005, mapped with a GPS and coordinates transferred to the GIS (Fig. 1). This corresponds to a representative sample of $82 \%$ of all cattle post and farms in the three survey blocks. To assess the extent of human-carnivore conflicts, 77 interviews were conducted in Setswana by two native speakers (LM and KK) using a pretested short questionnaire and following the recommendations of White et al. (2005). Cattle post attendants and farmers were asked accounting questions relating to changes in livestock numbers and experiences with predator attacks on livestock. If a loss due to predators was reported, respondents were asked further details about the attack. As a conservative estimate, a reporting period spanning the previous 12 months was assumed. Compiled questionnaire data were analysed using $\chi^{2}$ tests. All statistical tests were two-tailed with significance level set at $\mathrm{P}=0.05$, and were run on Systat v. 10 (Systat Software, Chicago, USA).

\section{Results}

A total of 938 predator attacks were reported (Table 1), the majority of which (99\%) were fatal, causing an estimated financial loss of BWP 350,000 (USD 57,000). Significantly fewer predator attacks per cattle post were reported in the Shorobe survey block compared to the other two blocks $\left(\chi^{2}=416.6, \mathrm{df}=2, \mathrm{P}<0.001\right)$, but a larger proportion of those reports involved the two largest predator species (lion and spotted hyaena combined $=58 \%$ ). Cattle posts in the Shorobe survey block reported significantly higher frequencies and constituted the majority of lion $(86 \%)$ and spotted hyaena $(73 \%)$ attacks (lion: $\chi^{2}=94.0, \mathrm{df}=2, \mathrm{P}<0.001$; spotted hyaena: $\left.\chi^{2}=86.0, \mathrm{df}=2, \mathrm{P}<0.001\right)$. Reported conflicts involving these two predator species thus declined with increasing distance from protected areas (Table 1). However, the highest frequency of predator attacks was reported in the Hainaveldt survey block because of a significantly larger proportion ( $72 \%)$ of predation events attributed to black-backed jackal $\left(\chi^{2}=789.7, \mathrm{df}=2, \mathrm{P}<0.001\right)$. In total, the five largest predator species (lion, leopard, cheetah, spotted hyaena and wild dog) combined from all three survey blocks constituted $22 \%$ of all predator attacks reported, with most attacks ( $77 \%$ ) being blamed on blackbacked jackal (Table 1).

The results indicate that wild dogs were not a major cause of livestock losses, despite the presence of two resident packs before and during the survey (Fig. 1). Wild dogs accounted for only $2 \%$ of the reported predator attacks, although they were frequently located in the immediate vicinity of numerous cattle posts and farms. In the two survey areas where the distribution of wild dogs was known, an estimated $6 \%$ of their prey was derived from unattended livestock, based upon an average rate of prey capture for wild dogs (McNutt \& Boggs, 1996) and the reports of livestock losses attributed to wild dogs during the 6 months prior to and during the survey period. Despite their low impact on livestock, six adults and 19 pups from the two packs were killed (presumably shot) within the 3 months immediately following this survey, with only two adults known to have survived in the survey areas.

Internal consistency was lacking in the professed knowledge of those interviewed regarding predation events. In answers to specific questions about predator attacks, respondents claimed knowledge of nearly all livestock losses, with only $2 \%$ reported as 'carcass not found' (reports indicated that 'spoor observed provided evidence to infer cause of disappearance'). However, in questions referring

TABLE 1 Reported predator attacks on livestock in the three survey blocks (Fig. 1) in northern Botswana with increasing distance (left to right) from protected areas (percentages in parentheses).

\begin{tabular}{|c|c|c|c|c|}
\hline \multirow[b]{2}{*}{ Species } & \multicolumn{4}{|c|}{ Survey block (no. of interviews) } \\
\hline & Shorobe (33) & Samedupi (27) & Hainaveldt (17) & Total (77) \\
\hline Lion Panthera leo & $43(26.1)$ & $5(2.3)$ & $2(0.4)$ & $50(5.3)$ \\
\hline Leopard Panthera pardus & $12(7.3)$ & $17(7.7)$ & $17(3.1)$ & $46(4.9)$ \\
\hline Cheetah Acinonyx jubatus & $0(0.0)$ & $13(5.9)$ & $0(0.0)$ & $13(1.4)$ \\
\hline Caracal Caracal caracal & $5(3.0)$ & $1(0.5)$ & $4(0.7)$ & $10(1.1)$ \\
\hline Spotted hyaena Crocuta crocuta & $53(32.1)$ & $19(8.6)$ & $1(0.2)$ & $73(7.8)$ \\
\hline Wild dog Lycaon pictus & $12(7.3)$ & $7(3.2)$ & $3(0.5)$ & $22(2.3)$ \\
\hline Black-backed jackal Canis mesomelas & $40(24.2)$ & $160(72.1)$ & $524(95.1)$ & $724(77.2)$ \\
\hline Total & $165(17.6)$ & $222(23.7)$ & $551(58.7)$ & $938(100.0$ \\
\hline
\end{tabular}


specifically to changes in livestock numbers, a substantial proportion of animals ( $22 \%$ of all causes of declining herd size, $\mathrm{n}=2,105$, including sales, and $33 \%$ of all livestock disappearances, $\mathrm{n}=1,405$ ) could not be accounted for. These were assumed to have been 'lost to predators'. Similarly, results indicate that respondents rarely kept records of their lost livestock. For example, only $37 \%$ of livestock reported to have been attacked by predators could be identified by age. Where age was specified, juveniles were the most commonly attacked age group (54\%), followed by adults (43\%). Predation on newborns was notably low $(3 \%)$, although there was inconsistency in distinguishing newborns from juveniles in this survey.

Most predator attacks were reported to have occurred outside traditional corrals (kraals; 85\%). Slightly more than half of the predator attacks (55\%) were reported to have occurred during the day, but verifying this claim was difficult because animals left out at night are, at best, only found in daylight. Predator attacks reported were not in proportion to the relative abundance of livestock (Fig. 2). Goats were significantly more likely to be reported as lost to predators $\left(\chi^{2}=12.5, \mathrm{df}=1, \mathrm{P}<0.001\right)$, predominantly to black-backed jackal. The converse was true for cattle $\left(\chi^{2}=45.4, \mathrm{df}=1, \mathrm{P}<0.001\right)$. Overall livestock abundance is increasing in the study area, with more than double the number of livestock reported as added to the herds ( $\mathrm{n}=$ 4,309 births and purchases) than were lost due to various causes, including sales.

\section{Discussion}

Our survey of human-carnivore conflicts revealed that livestock losses caused by predators represent an economic concern for livestock owners in northern Botswana. Studies elsewhere have shown that tolerance of overlapping predators by local communities usually depends on the extent of predation on their livestock (Rasmussen, 1999; Patterson et al., 2004; Woodroffe et al., 2005; Kolowski \& Holekamp, 2006; Holmern et al., 2007). Our results indicate that it was not the largest predator species ranging onto communal land adjacent to protected areas that caused the most problems, but black-backed jackal on farms furthest away from the veterinary cordon fence. The frequency of reported black-backed jackal attacks on livestock was inversely proportional to those by larger predators. This may be explained by competitive release of black-backed jackal from superior competitors and predators, such that their abundance increases with increasing distance from protected areas (meso-predator release; Elmhagen \& Rushton, 2007). Our results suggest that leaving livestock, particularly goats, unattended during daylight increases the likelihood of livestock predation, irrespective of the predator implicated. Furthermore, our results corroborate studies from elsewhere that predation may be reduced by kraaling livestock at night, if adjusted for type of livestock kept and predator involved (Ogada et al., 2003; Woodroffe et al., 2007a). The importance of wildlife-based tourism to Botswana's economy should lend urgency to the need for livestock owners to take greater responsibility for their animals by attending them during daylight, kraaling them at night, and keeping accurate records of livestock losses (Schiess-Meier et al., 2007).

Despite an existing scheme to compensate for livestock losses caused by predators (Tjibae, 2001), our results indicate that compensation payments did not demonstrably change livestock owners' willingness to coexist with predators. Predator attacks on livestock continue to ignite and fuel negative attitudes towards wildlife and government efforts to conserve it. In an attempt to safeguard their livelihoods, some livestock owners resort to the illegal practice of killing predators because they are not satisfied with the government's response to their problems (real and/or perceived). Similar experiences regarding the importance of taking issues raised by local communities seriously in predator conservation have been documented (Marker et al., 2003; Davies \& Du Toit, 2004; Lindsey et al., 2005; Romañach et al., 2007; Gusset et al., 2008; Selebatso et al., 2008; Lagendijk \& Gusset, in press). In the light of growing livestock numbers, our results thus suggest that Botswana's compensation policy merits revision. For example,

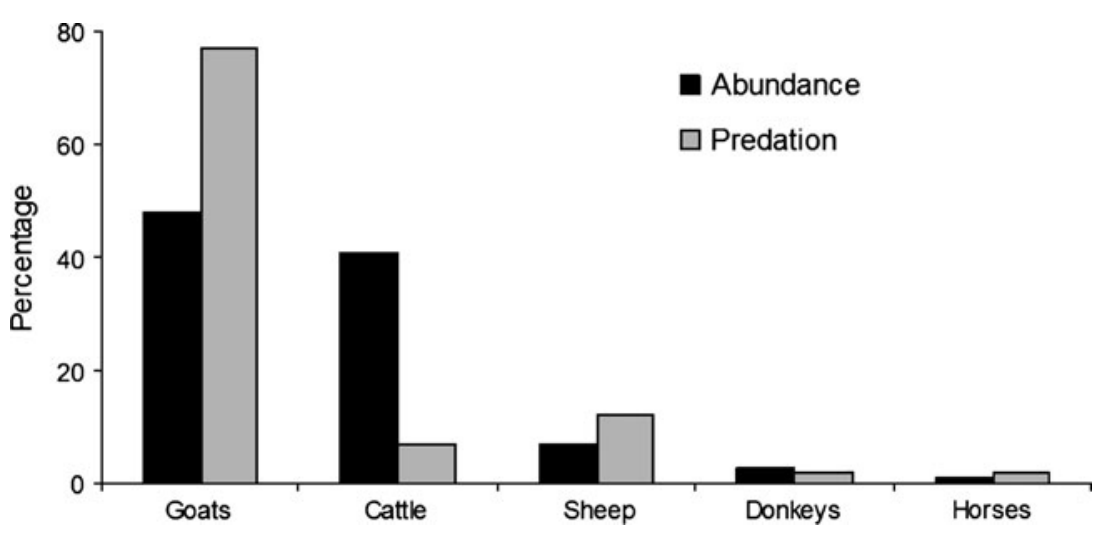

FIG. 2 Reported predator attacks on livestock in northern Botswana relative to livestock abundance. Goats were significantly more likely to be reported as lost to predators $\left(\chi^{2}=12.5, \mathrm{df}=1, \mathrm{P}<0.001\right)$, whereas the converse was true for cattle $\left(\chi^{2}=45.4, \mathrm{df}=1, \mathrm{P}<0.001\right)$. 
the question of why livestock losses from predation by black-backed jackal, spotted hyaena and caracal are currently not compensated for should be addressed. Similarly, the government should continue to compensate only those livestock owners who adhere to minimal standards of responsible livestock husbandry practices, possibly in conjunction with introducing penalties for false claims and for killing predators. Direct performance payments to livestock owners who demonstrate a tolerance for overlapping predators have been suggested as an alternative to compensating for livestock losses (Ferraro \& Kiss, 2002). Similar suggestions have been made to ameliorate humanelephant conflict in Botswana (Jackson et al., 2008).

Apart from direct observations (by JWM) of lethal control measures for wild dogs, the extent to which indiscriminate killing is affecting other predator species in northern Botswana remains unknown. Elsewhere in Africa, this impact has been found to be substantial (Woodroffe \& Frank, 2005), reducing population viability and the potential for generating revenues through predator-based tourism (consumptive and non-consumptive). Nevertheless, predators often manage to survive in human-dominated landscapes (Linnell et al., 2001), as exemplified by wild dogs before and during this survey, although they were effectively extirpated from the survey areas in the following months. Importantly, human persecution thus apparently continues, although wild dogs appear rarely to kill livestock in northern Botswana, as they subsist on small game even when resident in livestock grazing areas (Woodroffe et al., 2007b). Accordingly, livestock losses in our survey were higher in areas where wild prey had been depleted (McNutt \& Boggs, 1996), which highlights the importance of conserving wildlife alongside livestock to minimize predator attacks.

In conclusion, adequately addressing human-wildlife conflicts to lower costs and enhance benefits resulting from the presence of wildlife is expected to promote wildlife conservation and sustainable use initiatives, such as CBNRM programmes, as a potentially important area of economic growth in developing countries (Berkes, 2007). Quantitative information on both real and perceived conflicts attributed to free-ranging large carnivores, as presented here, is essential to address this management imperative.

\section{Acknowledgements}

We are grateful to the Ministry of Environment, Wildlife and Tourism and the Department of Wildlife and National Parks for permission to conduct research in Botswana. This work was supported by grants from the National Geographic Society, the Lee and Juliet Folger Foundation and $\mathrm{H}$. Gale. Two anonymous referees provided helpful comments.

\section{References}

Arntzen, J.W., Molokomme, D.L., Terry, E.M., Moleele, N., Tshosa, O. \& Mazambani, D. (2003) Main Findings of the Review of CBNRM in Botswana. CBNRM Support Programme Occasional Paper No. 14. IUCN, Gaborone, Botswana.

Berkes, F. (2004) Rethinking community-based conservation. Conservation Biology, 18, 621-630.

BERKES, F. (2007) Community-based conservation in a globalized world. Proceedings of the National Academy of Sciences of the USA, 104, 15188-15193.

Davies, H.T. \& Du Toit, J.T. (2004) Anthropogenic factors affecting wild dog Lycaon pictus reintroductions: a case study in Zimbabwe. Oryx, 38, 32-39.

Du Toit, J.T. (2002) Wildlife harvesting guidelines for communitybased wildlife management: a southern African perspective. Biodiversity and Conservation, 11, 1403-1416.

Elmhagen, B. \& Rushton, S.P. (2007) Trophic control of mesopredators in terrestrial ecosystems: top-down or bottom-up? Ecology Letters, 10, 197-206.

Ferraro, P.J. \& Kiss, A. (2002) Direct payments to conserve biodiversity. Science, 298, 1718-1719.

Gusset, M., Maddock, A.H., Gunther, G.J., Szykman, M., Slotow, R., Walters, M. \& Somers, M.J. (2008) Conflicting human interests over the re-introduction of endangered wild dogs in South Africa. Biodiversity and Conservation, 17, 83-101.

Holmern, T., Nyahongo, J. \& Røskaft, E. (2007) Livestock loss caused by predators outside the Serengeti National Park, Tanzania. Biological Conservation, 135, 534-542.

IUCN (2007) 2007 IUCN Red List of Threatened Species. IUCN, Gland, Switzerland. Http://www.iucnredlist.org [accessed 3 September 2008].

Jackson, T.P., Mosojane, S., Ferreira, S.M. \& van Aarde, R.J. (2008) Solutions for elephant Loxodonta africana crop raiding in northern Botswana: moving away from symptomatic approaches. Oryx, 42, 83-91.

Kolowski, J.M. \& Holekamp, K.E. (2006) Spatial, temporal, and physical characteristics of livestock depredations by large carnivores along a Kenyan reserve border. Biological Conservation, $128,529-541$.

Lagendijk, D.D.G. \& Gusset, M. (in press) Human-carnivore coexistence on communal land bordering the Greater Kruger Area, South Africa. Environmental Management.

Lindsey, P.A., Du Toit, J.T. \& Mills, M.G.L. (2005) Attitudes of ranchers towards African wild dogs Lycaon pictus: conservation implications on private land. Biological Conservation, 125, 113-121.

Linnell, J.D.C., Swenson, J.E. \& Andersen, R. (2001) Predators and people: conservation of large carnivores is possible at high human densities if management policy is favourable. Animal Conservation, 4, 345-349.

Madden, F. (2004) Creating coexistence between humans and wildlife: global perspectives on local efforts to address humanwildlife conflict. Human Dimensions of Wildlife, 9, 247-257.

Marker, L.L., Mills, M.G.L. \& Macdonald, D.W. (2003) Factors influencing perceptions of conflict and tolerance towards cheetahs on Namibian farmlands. Conservation Biology, 17, 1290-1298.

McNutt, J.W. (1996) Sex-biased dispersal in African wild dogs, Lycaon pictus. Animal Behaviour, 52, 1067-1077.

McNutt, J.W. \& Boggs, L.P. (1996) Running Wild: Dispelling the Myths of the African Wild Dog. Smithsonian Institution Press, Washington, DC, USA.

Ogada, M.O., Woodroffe, R., OGuge, N.O. \& Frank, L.G. (2003) Limiting depredation by African carnivores: the role of livestock husbandry. Conservation Biology, 17, 1521-1530. 
Osofsky, S.A., McNutt, J.W. \& Hirsch, K.J. (1996) Immobilization of free-ranging African wild dogs (Lycaon pictus) using a ketamine/xylazine/atropine combination. Journal of Zoo and Wildlife Medicine, 27, 528-532.

Patterson, B.D., Kasiki, S.M., Selempo, E. \& Kays, R.W. (2004) Livestock predation by lions (Panthera leo) and other carnivores on ranches neighbouring Tsavo National Parks, Kenya. Biological Conservation, 119, 507-516.

Rasmussen, G.S.A. (1999) Livestock predation by the painted hunting dog Lycaon pictus in a cattle ranching region of Zimbabwe: a case study. Biological Conservation, 88, 133-139.

Romañach, S.S., Lindsey, P.A. \& Woodroffe, R. (2007) Determinants of attitudes towards predators in central Kenya and suggestions for increasing tolerance in livestock dominated landscapes. Oryx, 41, 185-195.

Schiess-Meier, M., Ramsauer, S., Gabanapelo, T. \& König, B. (2007) Livestock predation - insights from problem animal control registers in Botswana. Journal of Wildlife Management, 71, 1267-1274.

Selebatso, M., Moe, S.R. \& Swenson, J.E. (2008) Do farmers support cheetah Acinonyx jubatus conservation in Botswana despite livestock depredation? Oryx, 42, 430-436.

Sillero-Zubiri, C. \& Laurenson, M.K. (2001) Interactions between carnivores and local communities: conflict or coexistence? In Carnivore Conservation (eds J.L. Gittleman, S.M. Funk, D. Macdonald \& R.K. Wayne), pp. 282-312. Cambridge University Press, Cambridge, UK.

Tлів ае, M. (2001) Overview of problem animal control. In National Technical Predator Management and Conservation Workshop in Botswana, pp. 25-34. Department of Wildlife and National Parks, Gaborone, Botswana.

Treves, A. \& Karanth, K.U. (2003) Human-carnivore conflict and perspectives on carnivore management worldwide. Conservation Biology, 17, 1491-1499.

White, P.C.L., Vaughan Jennings, N., Renwick, A.R. \& BARKER, N.H.L. (2005) Questionnaires in ecology: a review of past use and recommendations for best practice. Journal of Applied Ecology, 42, 421-430.
Woodroffe, R. \& Frank, L.G. (2005) Lethal control of African lions (Panthera leo): local and regional population impacts. Animal Conservation, 8, 91-98.

Woodroffe, R., Frank, L.G., Lindsey, P.A., Ole Ranah, S.M.K. \& RomañACH, S. (2007a) Livestock husbandry as a tool for carnivore conservation in Africa's community rangelands: a casecontrol study. Biodiversity and Conservation, 16, 1245-1260.

Woodroffe, R. \& Ginsberg, J.R. (1998) Edge effects and the extinction of populations inside protected areas. Science, 280, 2126-2128.

Woodroffe, R., Lindsey, P.A., Romañach, S.S. \& Ole Ranah, S.M.K. (2007b) African wild dogs (Lycaon pictus) can subsist on small prey: implications for conservation. Journal of Mammalogy, $88,181-193$.

Woodroffe, R., Lindsey, P., Romañach, S., Stein, A. \& Ole RanaH, S.M.K. (2005) Livestock predation by endangered African wild dogs (Lycaon pictus) in northern Kenya. Biological Conservation, 124, 225-234.

\section{Biographical sketches}

Markus Gusset did postdoctoral research in the Botswana Predator Conservation Program and now heads the conservation department at Leipzig Zoo. He is interested in carnivore behaviour, ecology and conservation. Matthew J. Swarner is a PhD student in the Botswana Predator Conservation Program, focusing his interests on human-carnivore conflicts in central and western Botswana. Letsogile Mponwane and Kenosi Keletile work for Botswana's Department of Wildlife and National Parks and were seconded to the Botswana Predator Conservation Program for this study. J.W. 'Tico' McNutt leads the Botswana Predator Conservation Program and has studied wild dogs in northern Botswana since 1989. He has recently expanded the project to include all members of the large predator guild, focusing his interests on behavioural ecology and communication systems to aid carnivore conservation. 